\title{
PENDEKATAN SEMI-AUTONOMOUS SOCIAL FIELD DALAM STUDI DAN PERENCANAAN PERKOTAAN: TELAAH METODOLOGIS
}

\author{
Erwin Fahmi \\ Program Studi Magister Perencanaan Wilayah dan Kota, Universitas Tarumanagara \\ Email:erwin.fahmi@gmail.com
}

Masuk: 16-08-2021, revisi: 23-09-2021, diterima untuk diterbitkan: 06-10-2021

\begin{abstract}
ABSTRAK
Kajian ini membahas pendekatan yang lazim digunakan dalam kajian antropologi hukum, yaitu bidang sosial semiotonom, dan potensi penerapannya dalam bidang studi dan perencanaan perkotaan. Pendekatan ini dipandang sangat relevan karena menjelaskan apa dan mengapa terjadi perbedaan antara apa yang ditetapkan oleh kebijakan negara (termasuk rencana tata ruang) dan apa yang sesungguhnya diterima dan diterapkan dalam bidang sosial semi-otonom, seperti komunitas atau organisasi/perusahaan. Dengan memahami ketidaksesuaian tersebut kita dapat mengapresiasi keberadaan norma, nilai dan kebiasaan lokal dan karenanya juga dapat menghargai pluralisme hukum. Sekali lagi, sebagai produk hukum, rencana kota juga terikat pada pemahaman semacam itu. Dua contoh digunakan untuk mengilustrasikan penerapan pendekatan ini. Dalam kedua contoh, proses-proses elaborasi, penyesuaian, penerimaan, dan konflik ditunjukkan.
\end{abstract}

Kata kunci: bidang sosial semi-otonom; aturan-pakai; studi dan perencanaan perkotaan

\begin{abstract}
This study discusses an approach widely used in the study of legal anthropology, i.e., semi-autonomous social field, for its potential application in the fields of urban studies and planning. This approach is considered highly relevant as it explains what and why discrepancies take place between what is dictated by state policy (including spatial planning) and what is actually accepted and applied in a semi-autonomous social field, like community or organization/company. By understanding these discrepancies, we may be able to appreciate the existence of local norms, values, and habits and, therefore, also of legal pluralism. Once again, as a legal product, urban plan is also bound to such an understanding. Two examples are taken to illustrate the application of this approach. In both illustrations, processes of elaboration, adjustment, acceptance, and conflict were demonstrated.
\end{abstract}

Keywords: semi autonomous social field; rules-in-use; urban studies and planning.

\section{PENDAHULUAN}

\section{Latar Belakang}

Perkembangan pesat ilmu pengetahuan dan teknologi dimungkinkan, antara lain, karena kesepakatan metodologis yang disebut eklektisisme. Menurut Cambridge Dictionary, eclecticism (kata benda) adalah: "the fact of combining things from many different areas or systems". Dalam khasanah ilmu pengetahuan dan teknologi, eklektisisme dimaknai sebagai paham tentang saling meminjam teori, pendekatan dan/atau metode antar-berbagai bidang ilmu. Dengan pinjammeminjam teori, pendekatan dan/atau metode dari bidang kajian lain, suatu bidang kajian tertentu dapat melakukan terobosan, menjelaskan apa dan mengapa suatu fenomena tertentu yang berada di batas-batas bidang ilmunya, dapat terjadi dan bagaimana prospeknya ke depan. Dengan cara demikian pula, bidang kajian tersebut, juga ilmu pengetahuan umumnya, baik dalam rumpun ilmuilmu alam maupun ilmu-ilmu sosial, dapat terus berkembang.

Studi dan perencanaan perkotaan (urban studies and planning) adalah 2 bidang kajian yang bersifat multi-disiplin (melibatkan dan mengaitkan berbagai disiplin ilmu) dan trans-disiplin (melampaui 
batas-batas disiplin ilmu tertentu). Dalam setengah abad terakhir, dua bidang tersebut dibentuk dan diperkaya oleh bidang-bidang kajian lain, seperti arsitektur, teknik sipil, sosiologi, ilmu ekonomi, ilmu hukum, kebijakan publik, dan sebagainya (Friedmann 1987). Karena itu, 2 bidang kajian tersebut sangat akrab dengan, dan berkembang melalui, eklektisisme.

Pendekatan bidang sosial semi-otonom (semi-autonomous social field - SASF) adalah pendekatan yang berkembang dalam bidang antropologi hukum. Pendekatan ini dirintis oleh Sally Falk Moore (1973: 719-746) melalui publikasinya "Law and Social Change: The Semi-autonomous Social Field as an Appropriate Subject of Study". Dalam publikasi tersebut, Moore menunjukkan bahwa:

a. SASF adalah lokus dan focus kajian yang tepat, karena dapat menggambarkan bagaimana inovasi hukum dan kebijakan negara bekerja dan mendorong perubahan sosial dalam masyarakat (Moore 1973: 719; Ihromi 1993: xiv). Hal ini menegaskan pemikiran Pound (dalam Moore 1973: 719), bahwa hukum adalah alat untuk rekayasa sosial (social engineering);

b. SASF juga menggambarkan seberapa jauh ketaatan kepada hukum, atau kebijakan negara lainnya, ditentukan, atau perlu dikaitkan dengan, berbagai aturan sosial di tempat interaksiinteraksi antara berbagai pelaku tersebut berlangsung (Ihromi 1993: xiv). Dengan demikian, pendekatan SASF membuka pemahaman sejauh mana dan mengapa aturan-pakai negara, misalnya, mengalami diskrepansi ketika diterapkan pada satu bidang sosial tertentu. Dalam konteks itu, hukum atau kebijakan negara mengalami 'penyesuaian' ketika bertemu hukum atau kebijakan setempat.

Kebijakan atau hukum secara umum dapat disebut institusi; menurut E. Ostrom (1992: 19) institusi adalah "... the set of rules actually used (the working rules or rules-in-use) by a set of individuals to organize repetitive activities that produce outcomes affecting those individuals and potentially affecting others". Demikianlah, maka negara/kota, sebagai bidang sosial yang lebih besar, dapat saja menerapkan rules-in-use (aturan-pakai) baru dan dipaksakan berlaku pada SASF (sebagai bidang sosial yang lebih kecil) tersebut.

Setelah publikasi Moore tersebut, pendekatan SASF luas dimanfaatkan, terutama oleh pengkaji bidang antropologi, bidang hukum, dan bidang antropologi hukum. Dari berbagai studi, sekurangkurangnya ada 2 manfaat pendekatan SASF. Pertama, pendekatan SASF membantu menjelaskan mengapa terjadi diskrepansi antara hukum dan kebijakan negara dalam penerapannya pada suatu bidang sosial semi otonom tertentu. Alasan di balik diskrepansi tersebut adalah karena kebijakan dimaksud (= aturan-pakai negara) dapat mengalami penyesuaian-diri, kompromi atau konflik dalam interaksinya dengan aturan-pakai SASF setempat (Ihromi 1993). Kedua, pendekatan SASF digunakan untuk menginterpretasikan nilai-nilai dan perilaku sosial warga suatu komunitas, melalui sikapnya terhadap suatu sengketa hukum/kebijakan tertentu. Dalam konteks ini, sengketa adalah 'jendela' untuk menginterpretasikan nilai-nilai dan perilaku sosial, bahkan juga struktur sosial, dalam masyarakat tersebut. Studi Zakaria (2002) tentang nilai-nilai dan perilaku sosial suku-suku di Flores Timur, yang diinterpretasikan dari kasus sengketa perebutan tanah adat, termasuk kategori ini.

Dengan pemahaman tersebut, relevansi SASF bagi studi dan perencanaan perkotaan tampak jelas. Salah satu fokus studi dan perencanaan perkotaan adalah mengkaji seberapa jauh dan mengapa suatu produk hukum, misalnya rencana tata ruang wilayah kota (RTRWK) dipatuhi, atau disimpangkan 
oleh dan dalam masyarakat; bagaimana masyarakat di tingkat lokal sesungguhnya menanggapi penerapan RTRWK tersebut; sejauhmana RTRWK mendorong perubahan sosial dalam masyarakat. Bahkan, sebagaimana akan ditunjukkan di bawah, bagaimana relevansi suatu UU Penataan Ruang yang dirancang dengan asumsi situasi normal tertentu - ketika diterapkan pada suatu situasi dan konteks sosial tertentu, misalnya pasca-bencana skala besar.

Interaksi antara aturan-pakai yang dikembangkan oleh suatu SASF dan aturan-pakai yang dipaksakan dari lingkungan sosial yang melingkupinya, seperti aturan-pakai negara, dapat menimbulkan 3 kemungkinan akibat pada SASF:

a. patuh dan menyesuaian diri;

b. kompromi; dan

c. penolakan/konflik.

Sejarah pemikiran perencanaan pernah mencatat suatu konsep yang diketengahkan melalui gugatan hukum, dan berhasil menjadi konsep yang unggul dan diterapkan secara luas sampai sekarang. Konsep tersebut, yakni advocacy planning, dirumuskan oleh Paul Davidoff (1930 - 1984), seorang perencana kota dan praktisi hukum, dan istrinya, Linda Stone Davidoff, pada awal dekade 1960-an melalui gugatan terhadap eksklusivitas zonasi permukiman ke pengadilan. Gugatan di pengadilan negeri New Jersey, Amerika Serikat, tersebut mewakili kepentingan kelompok masyarakat kulit berwarna terhadap rencana tata ruang di suatu suburban. Rencana tata ruang tersebut dinilai diskriminatif terhadap warga miskin/warga kulit berwarna. Gugatan dimenangkan oleh masyarakat kulit berwarna tersebut dan hasil sengketa ini kemudian terkenal sebagai "Mount Laurel Doctrine": bahwa setiap komunitas perlu menyediakan alokasi yang adil bagi perumahan MBR (masyarakat berpendapatan rendah) dan/atau kulit berwarna (https://peoplepill.com/people/paul-davidoff/2. Pada saat ini, advocacy planning merupakan salah satu rumpun teori penting dalam perencanaan perkotaan (Galloway dan Kaufman 1979: 387-398).

\section{Rumusan Masalah}

Fokus kajian ini adalah memeriksa kesesuaian dan kelayakan pendekatan SASF dalam studi dan perencanaan perkotaan. Pengayaan pendekatan dalam studi dan perencanaan perkotaan adalah keniscayaan mengingat sejarah dan karakter kedua bidang kajian itu, dan fakta bahwa kehidupan perkotaan, dan arah-arah perkembangannya ke depan, semakin kompleks. Karena itu, diperlukan alat bantu yang semakin beragam, seperti pendekatan SASF, untuk memahami kompleksitas permasalahan yang dikaji.

\section{Tujuan Penelitian}

Tujuan penelitian ini adalah menjelaskan tentang apa, bagaimana dan mengapa sering terjadi diskrepansi antara apa yang ditetapkan dalam produk kebijakan formal (termasuk rencana kota) dan apa yang nyatanya dijalankan dalam kehidupan sehari-hari. Dengan penjelasan tersebut, diharapkan tumbuh pemahaman yang lebih baik tentang pluralisme hukum, atau sekurang-kurangnya kebijaksanaan dalam mendorong penerapan suatu kebijakan pada suatu konteks atau bidang sosial tertentu. 


\section{METODE PENELITIAN}

Penelitian ini menggunakan pendekatan kualitatif-deskriptif untuk memahami konsep dan konteks keberlakuan pendekatan SASF. Untuk keperluan itu, gagasan awal dan konsep pokok Sally Falk Moore (1973) akan dibahas secara mendalam. Selain itu, untuk mengilustrasikan penerapannya, 2 kasus berkaitan dengan studi dan perencanaan perkotaan di Indonesia akan dibahas. Kedua kasus tersebut, sampai tingkat tertentu, mewakili kedua kategori manfaat SASF.

Metode pengumpulan data dan analisis pada kasus I, yakni kasus perencanaan tata ruang Aceh pasca-bencana, 2005-2009, adalah metode action-research. Melalui keterlibatan sebagai pelaku, penulis berkesempatan mencatat secara dekat berbagai diskusi berkaitan dengan keberatan atau ketidakmungkinan penerapan sebagian ketentuan-ketentuan dalam UU 24/1992 tentang Penataan Ruang dalam situasi rehabilitasi-rekonstruksi (R/R) pasca bencana dahsyat di Aceh saat itu, dan apa alternatif yang mungkin. Selain itu, catatan tersebut juga diperkaya dengan pengalaman lapangan selama proses $\mathrm{R} / \mathrm{R}$ berlangsung. Catatan tersebut kemudian juga mendapat konfirmasi melalui sejumlah kajian akademis, antara lain dari Pardede dan Tetsuo (2008) dan Fahmi (2021). Sementara, pada kasus II, yakni studi tentang kampung Leuser di Kebayoran Baru, penulisnya menggunakan metode pengumpulan data dan analisis kualitatif. Pada penelitian tersebut, penulis yang bersangkutan menggunakan teknik observasi dengan pengamatan terlibat, dan telaah sengketa hukum yang telah mengemuka di pengadilan antara masyarakat setempat dan BPN (Badan Pertanahan Nasional). Melalui sengketa, sudut pandang, nilai-nilai dan sikap masyarakat Kampung Leuser dapat dipelajari.

Studi ini menarik dan penting karena, meskipun relatif jelas (obvious) dari perspektif kebijakan publik, namun dalam praktik studi dan perencanaan perkotaan, khususnya di Indonesia, pendekatan SASF belum cukup dikenal alih-alih diterapkan. Mengapa? Karena studi dan perencanaan perkotaan, dalam tradisi masyarakat yang belum sepenuhnya demokratis, cenderung diartikan sebagai pengaturan masyarakat menurut arahan dan ketetapan pemerintah. Dengan kata lain, produk hukum seperti Perda (peraturan daerah) tentang RTRWK adalah mekanisme untuk melakukan kendali dan perubahan sosial (lihat juga: Moore [1973: 719]). Arahan dan ketetapan bukan sesuatu yang dapat atau lazim ditantang (challenged), apalagi secara terbuka melalui sengketa.

\section{HASIL PENELITIAN DAN PEMBAHASAN Pendekatan SASF}

Moore (1973) mengembangkan pendekatan SASF dari penelitiannya tentang kaitan inovasi hukum dan perubahan sosial. Dalil Moore, sebagaimana dikatakan oleh Ihromi (1993: xiv), adalah: “...untuk mengetahui sampai seberapa jauh hukum dapat mengakibatkan perubahan sosial, maka perlu dikaji bagaimana hukum itu bekerja dalam kehidupan sehari-hari”. Menurut Moore (1973: 720), bidang atau lingkungan sosial (social field) yang semi-otonom adalah lingkungan sosial yang cukup besar untuk dapat mengembangkan aturan-pakainya sendiri, namun cukup kecil untuk dipengaruhi atau diubah oleh aturan-pakai dan keputusan yang diintroduksikan dari lingkungan yang mengungkungnya, misalnya aturan-pakai negara atau kota. Namun, Moore menekankan, SASF tidaklah ditentukan oleh besar-kecilnya lingkungan sosial tersebut, tapi oleh bekerjanya suatu proses sosial untuk menciptakan aturan-pakai yang dipatuhi dan dijalankan bersama oleh warga lingkungan sosial tersebut. Demikianlah, maka contoh lingkungan sosial semi-otonomi dimaksud, menurut Ihromi (1993: xv), termasuk keluarga, asrama, perusahaan, lingkungan ketetanggaan, dan satuan- 
satuan sosial yang berdasarkan agama. Secara diagramatis, pendekatan SASF ini dapat digambarkan sebagai berikut:

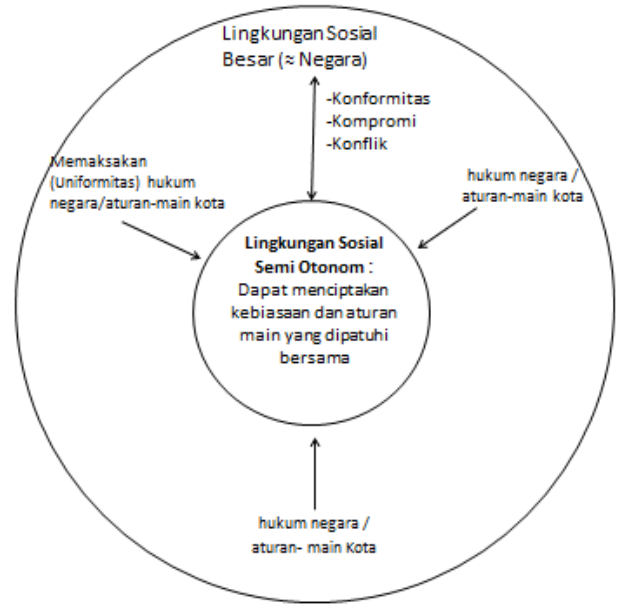

Gambar 1. Interaksi Lingkungan Sosial Semi-Otonom dengan Negara/Kota Sumber: Olahan penulis

\section{Keterangan:}

Panah satu arah: menggambarkan adanya berbagai aturan-pakai negara, atau lingkungan sosial yang lebih besar, yang dipaksakan pada lingkungan sosial semi-otonom.

Panah dua arah: menggambarkan penerimaan dan penyesuaian-diri, kompromi, atau konflik terjadi antara aturan-pakai negara/kota dan aturan-pakai bidang sosial semi-otonom. Dalam hal ini, aturan-pakai negara cenderung diterapkan dalam bidang sosial semi-otonom dalam batas-batas yang dapat diterima atau sejalan dengan aturan-pakai setempat.

Untuk mengilustrasikan pendekatannya, Moore (1973) menggunakan 2 kasus, yakni kasus industri garmen di New York dan kasus masyarakat suku Chagga di lereng Gunung Kilimanjaro, Tanzania. Dua kasus ini mengilustrasikan bagaimana lingkungan sosial dimaksud berhubungan (menyesuaikan-diri, berkompromi atau berkonflik) dengan aturan-pakai negara di luarnya:

a. Kasus industri garmen di New York. Dalam kasus ini, digambarkan bagaimana aturan-pakai formal yang diterapkan oleh institusi negara (berkaitan dengan jam kerja, keberadaan asosiasi buruh, dan sebagainya) sesungguhnya bekerja dalam konteks adanya aturan-pakai non-formal yang mengatur mekanisme kerja pihak-pihak tersebut sesuai tantangan dan kebiasaan khas pelaku-pelaku dalam industri tersebut. Sebagai contoh, agen asosiasi buruh yang seharusnya menolak penugasan buruh melebihi jumlah jam kerja tertentu, dapat saja mengabaikan ketentuan tersebut karena memiliki ketergantungan (sosial dan pekerjaan) pada kontraktor. Pengabaian jam kerja tidak jarang terjadi, khususnya pada musim fashion, atau menjelang awal musim ketika pekerjaan bisa sangat banyak; atau sebaliknya, yakni ketika paceklik job pada waktu yang lain. Demikian pula, hubungan antara bagian produksi (yang menentukan rincian kontrak para kontraktor) dan pemeriksa yang mewakili kepentingan pemborong (jobbers) dan floor lady yang mewakili kepentingan kontraktor. Hubungan kerja yang 'baik' memungkinkan terjadinya kompromi atau toleransi yang menguntungkan pihak-pihak terkait. 
b. Kasus masyarakat suku Chagga di Tanzania. Masyarakat suku Chagga yang mendiami lereng G. Kilimanjaro, Tanzania, adalah produsen kopi untuk pasar dunia. Hal ini sudah berlangsung beberapa dekade. Untuk menopang bisnis tersebut, serta memenuhi kebutuhan sendiri akan produk pertanian, suku Chagga mempraktekkan suatu mekanisme penguasaan tanah sesuai aturan dalam lingkungan sosial-kekerabatan setempat. Ketika jumlah warga relatif sedikit, dan tanah relatif luas, tiap orang yang memerlukan tanah dapat menguasai sesuai kebutuhannya. Pada masa itu, jual-beli tanah juga berlangsung antar-warga. Persoalan terjadi ketika negara, yang berusaha melembagakan paham sosialisme yang dianutnya, menghapuskan kepemilikan tanah secara pribadi dan menjadikannya sebagai milik negara. Penetapan ini muncul ketika sebagian besar tanah sesungguhnya telah menjadi milik anggota-anggota keluarga. Karena itu, penetapan ini menimbulkan sejumlah upaya untuk menyesuaikan pengaturan negara tersebut dengan kondisi setempat. Salah satunya, dengan menetapkan bahwa tanah kini berstatus hak garap pada tanah negara, meski sesungguhnya tanah-tanah tersebut tetap dikuasai oleh anggota-anggota keluarga dan berpindah tangan melalui transaksi bawah tangan atau mekanisme warisan yang telah berlangsung sejak jauh sebelumnya.

Dua ilustrasi di atas menegaskan ciri lain dari pendekatan SASF, yaitu:

a. Liatnya aturan-pakai lokal ketika berhadapan dengan aturan-pakai yang dipaksakan oleh lingkungan yang mengungkungnya. Terlebih ketika aturan-pakai lokal tersebut merupakan mekanisme untuk mempertahankan kelangsungan hidup (survival) komunitas;

b. Jalan tengah yang terjadi ketika aturan-pakai negara sangat kuat adalah penyesuaian-diri atau kompromi, berupa pemaknaan baru atas aturan-pakai yang dipaksakan tersebut. Dalam banyak kasus, kedua aturan-pakai dapat co-exist dengan sejumlah penyesuaian di sana-sini.

\section{Dua Kasus dari Khasanah Studi dan Perencanaan Perkotaan}

Ilustrasi berikut menggambarkan 2 kasus di Indonesia dalam bidang studi dan perencanaan perkotaan, untuk menunjukkan situasi dan tanggapan yang terjadi akibat penerapan suatu kebijakan, atau produk hukum tertentu, yakni UU Penataan Ruang (pada kasus rekonstruksi Aceh pascabencana) dan kebijakan RTH (ruang terbuka hijau) di DKI Jakarta. Ilustrasi berikut diharapkan dapat memperkaya pemahaman tentang pendekatan SASF dalam studi dan perencanaan perkotaan.

\section{A. Perencanaan tata ruang Aceh pasca-bencana, 2005-2009.}

Tantangan yang dihadapi dalam rehabilitasi/rekonstruksi (R/R) Aceh pasca-bencana gempa dan tsunami 26 Desember 2004 bersifat khas, dan dapat dipandang sebagai suatu lingkungan sosial semi-otonom (penjelasan lebih luas, lihat Fahmi dan Chandra-putra, 2021). Lingkungan tersebut dipandang semi-otonom karena situasi dan tantangan yang dihadapi sangat khas sehingga upaya $R / R$ tidak dapat menerapkan peraturan perundangan yang berlaku umum dan pada situasi normal. Hal ini ditunjukkan dengan terbitnya Peraturan Pemerintah Pengganti Undang-undang (Perppu) 2/2005 tentang Badan Rehabilitasi dan Rekonstruksi Aceh dan Nias (yang kemudian dikukuhkan menjadi UU 10/2005 tentang BRR), yang mengamanatkan "rekonstruksi wilayah dan kehidupan masyarakat" pasca-bencana. Ulasan berikut ini akan mengelaborasi situasi dan tantangan yang dihadapi, dan solusi yang ditawarkan, khususnya pada aspek penataan ruang.

Penataan ruang merupakan salah satu mandat R/R (Perppu 2/2005 tentang BRR pasal 5 [a]). Karena itu, rekonstruksi harus dimulai dan diarahkan melalui rencana tata ruang. Selanjutnya, Peraturan Presiden No 30/2005 tentang Rencana Induk R/R Aceh dan Nias mengamanatkan bahwa seluruh 
kota dan kabupaten terdampak harus memiliki RTRWK (Rencana Tata Ruang Wilayah Kota/Kabupaten) sesuai arahan UU 24/1992 tentang Penataan Ruang.

Namun, untuk memenuhi amanat di atas, 2 pertanyaan muncul:

a. Sesuai kandungan UU 24/1992 tentang Penataan Ruang, untuk menyusun RTRWK perlu terlebih dahulu disusun RTRWP (Rencana Tata Ruang Wilayah Provinsi); dan

b. Karena tingkat ke-detail-annya, RTRWK belumlah sepenuhnya operasional untuk memandu R/R. Agar operasional, perlu disusun arahan yang lebih rinci, yakni RDTRK (Rencana Detail Tata Ruang Kota) dan RTBL (Rencana Tata Bangunan dan Lingkungan). Setiap jenjang rencana tata ruang di atas, sesuai arahan UU 24/1992, harus disusun berurutan - rencana yang lebih rinci harus mengacu ke rencana yang lebih makro. Sementara, waktu yang diperlukan untuk menyusun setiap jenjang rencana di atas berkisar 6-8 bulan, dengan menganggap proses pengesahannya dapat berjalan cepat. Singkat kata, jika seluruh jenjang rencana tata ruang di atas disusun, maka tahap konstruksi R/R (pembangunan rumah, infrastruktur, dan sebagainya) baru dapat dimulai setelah tahun ke-3.

Tentu saja, jangka waktu di atas tidak dapat diterima. Pertama, karena korban bencana, yang telah tinggal berbulan-bulan di tenda dan barak pengungsi, ingin segera menempati rumah dan kembali ke kehidupan normal; dan kedua, mandat BRR hanya 4 tahun.

Singkat kata, tantangan yang dihadapi dalam R/R Aceh sangat khas, sehingga UU yang berlaku pada situasi normal dan untuk seluruh wilayah Indonesia, tidak dapat begitu saja dipedomani dalam konteks R/R. Dihadapkan pada tantangan $\mathrm{R} / \mathrm{R}$ di atas, tidak ada alternatif lain kecuali diperlukan terobosan. Terobosan yang akhirnya diterima dan diterapkan adalah perencanaan desa (village planning - VP); VP sebagaimana dikenal dalam R/R Aceh tidak dikenal dalam UU 24/1992 tentang Penataan Ruang. Penyusunan VP tidak menafikan keperluan untuk memenuhi amanat Perpres 30/2015 sebagaimana disebutkan terdahulu. VP adalah transitional plan; dalam proses penyusunan RTRWP, RTRWK dan RDTR yang secara paralel juga dilakukan sejak tahun I R/R untuk beberapa kota/kabupaten atau bagian wilayah kota, VP yang mungkin sedang disusun atau sedang diimplementasikan dapat diintegrasikan pada rencana tata ruang skala yang lebih besar tersebut. Untuk itu, diperlukan koordinasi yang intensif antar-pelaku penyusunan berbagai jenjang rencana tersebut. Tentu saja tidak selamanya penyesuaian dan integrasi tersebut berjalan mulus. Ketika rencana pembangunan jalan negara Banda Aceh - Meulaboh dicanangkan (dibiayai oleh USAID), trase jalan tersebut mengenai pinggiran beberapa gampong (yang dibangun dengan berpedoman pada VP). Akibatnya, beberapa rumah hasil rekonstruksi terpaksa dipindahkan ke lokasi yang lebih tepat. Di luar kasus-kasus yang jumlahnya terbatas, secara umum VP dapat relatif lancar diintegrasikan dengan rencana tata ruang jenjang di atasnya. 


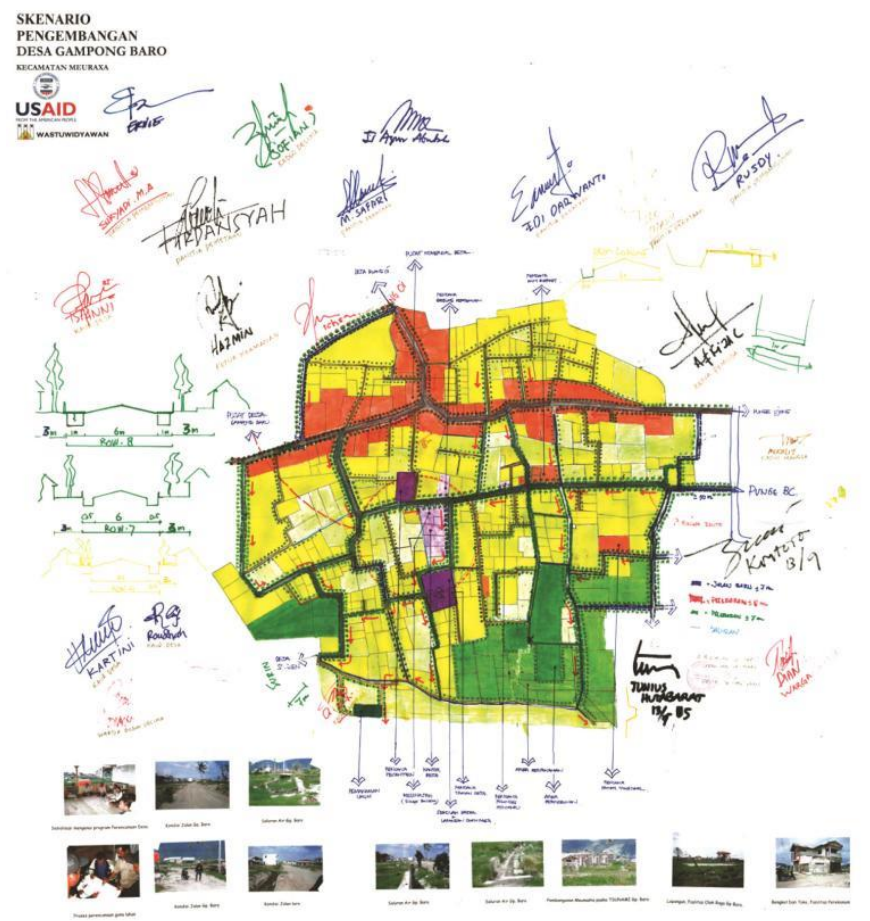

Gambar 2. Village Plan Gampong Baro, Banda Aceh Sumber: BRR, 2006

Keterangan: pengesahan VP dengan tanda tangan warga gampong bersangkutan dan pemukanya.

Introduksi VP tidak hanya merombak hierarkhi dan prosedur penyusunan rencana tata ruang namun juga pendekatan utama dalam penyusunan rencana tersebut. Pendekatan dominan yang berlaku dalam perencanaan tata ruang di Indonesia adalah pendekatan synoptic, mengikuti teori rational comprehensive planning. Pendekatan ini mengandaikan penerapan prinsip-prinsip science dalam perencanaan, antara lain melalui penggunaan prosedur baku tertentu (lihat Fahmi 2019). Tidak hanya dalam praktik perencanaan, pendekatan ini juga diindikasikan dalam kedua UU tentang Penataan Ruang, yakni UU 24 tahun 1992 dan, penggantinya, UU 26 tahun 2007 tentang Penataan Ruang. Dengan penerapan VP secara luas dalam R/R Aceh pasca-bencana, maka praktik perencanaan ini dapat disebut sebagai penerapan dalam skala besar pertama teori alternatif yang memayungi VP, yakni participatory planning (Hudson et al 1979: 387-398).

Penyesuaian dan inovasi hukum ini dilakukan untuk memenuhi beberapa tujuan, yaitu:

a. Agar R/R dapat memenuhi salah satu tujuan mendasarnya, yakni segera mengembalikan kehidupan warga korban bencana ke situasi normal; dan

b. Agar proses R/R dapat berjalan sesuai amanat UU 10/2005, yakni didahului dan mengikuti arahan rencana tata ruang.

Inovasi hukum di atas dimungkinkan karena adanya ruang diskresi dalam UU 10/2005 tentang BRR. Dalam Menimbang butir c UU tersebut, disebutkan bahwa “...penanganan rehabilitasi dan rekonstruksi ... harus dilaksanakan secara khusus, sistematis, terarah, dan terpadu serta menyeluruh 
dengan melibatkan partisipasi dan memperhatikan aspirasi serta kebutuhan masyarakat...". Diskresi dan inovasi hukum juga dibenarkan, karena dalam konteks tersebut UU 10/2005 tentang BRR adalah hukum yang bersifat khusus (lex specialis).

\section{B. Permukiman Kampung Leuser di Kebayoran Baru}

Dalam kajian yang menjadi tesis master di Universitas Tarumanagara ini, Roberto (2019) membahas persoalan Kampung Leuser di Kebayoran Baru. Permukiman informal ini telah tumbuh, menurut pengakuan warga, sejak 1955, berdasarkan ijin yang diberikan oleh PAM Jaya kepada petugasnya untuk bermukim di tanah tersebut. Tujuan pemberian ijin tersebut adalah agar petugas yang bersangkutan menjaga tanah (yang ada pompa, rumah pompa dan rumah dinas operator di atasnya) tersebut, dan bahwa penghuniannya bersifat sementara. Hal ini dibuktikan dengan surat yang dikeluarkan pada tahun 1960 oleh Ach. Djoenaedi selaku Kepala Bagian Saluran Air Minum P.C.K kepada Fatah selaku karyawan PAM Jaya. Sejak 2015, PAM Jaya berusaha mendapatkan kembali tanah yang telah berkembang menjadi permukiman padat tersebut, untuk diserahkan kepada Pemda DKI dan digunakan sebagai ruang terbuka hijau (RTH). Upaya tersebut ditentang oleh warga dan memuncak menjadi sengketa. Warga menggugat BPN (Badan Pertanahan Nasional), sebagai pihak yang mengeluarkan sertifikat HGB (Hak Guna Bangunan) bagi PAM Jaya atas lahan tersebut. Dalam persidangan di pengadilan Tata Usaha Negara (TUN) Jakarta (dan juga Mahkamah Agung), gugatan warga ditolak.

Sengketa ini menarik karena menyibakkan status penguasaan warga atas tanah tersebut, nilai-nilai yang mereka anut, dan perilaku sosial mereka. Pada saat-saat sengketa memuncak, struktur sosial warga juga tampak. Dengan mengacu ke Roberto (2019), berikut beberapa hal yang mengemuka:

Pertama, warga telah menghuni lahan tersebut secara terus menerus sejak lebih dari 60 tahun lalu, dan telah merawatnya dengan baik. Hal ini terbukti dari banyaknya piala yang terkumpul di ruang Sekretariat RT 008/08. Selain itu, sebagai warga yang baik, mereka juga telah membayar Pajak Bumi dan Bangunan dengan teratur. Berbagai infrastruktur dan pelayanan publik telah tersedia dengan memadai. Di kampung tersebut telah tersedia jaringan air bersih, saluran drainase, jalan setapak dan saluran pembuangan. Secara kolektif, warga juga telah membangun kantor sekretariat bersama yang menjadi ruang serbaguna (untuk rapat, atau perkumpulan pengurus kampung), dan rumah baca. Konstruksi bangunan rumah warga secara umum relatif baik dan permanen; meskipun kepadatan relatif tinggi, namun warga juga mampu menjaga lingkungan dan menjadikannya sebagai kampung hijau, 


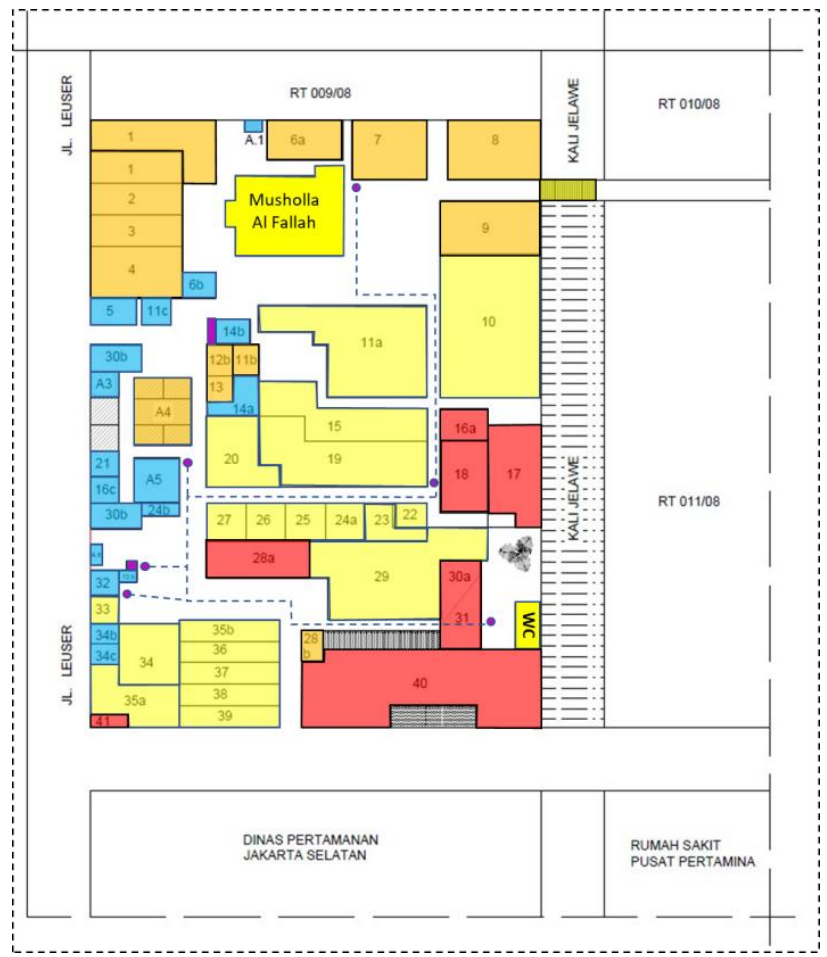

Gambar 3. Denah Kampung Leuser 2000-2005 Sumber: Roberto (2019)

Kedua, profil sosial-ekonomi warga dapat digambarkan melalui pekerjaan penduduk Kampung Leuser, yakni umumnya sebagai pekerja kantoran dan pedagang. Menurut seorang nara sumber sebagaimana dikutip dalam studi Roberto (2019), sekitar 60\% warga di Kampung Leuser bekerja sebagai pedagang di Pasar Mayestik, Kebayoran Baru. Selain itu, ada juga sekitar 20\% yang bekerja di instansi pemerintah, termasuk di PAM Jaya. Terakhir, ada sekitar 20\% warga yang membuka warung makan di sekitar Kampung Leuser. Bahkan salah satu warung makan di sana, yakni Rumah Makan Pak Tardja, sudah menjadi warung makan legendaris di Kebayoran Baru (Roberto dan Fahmi, akan terbit). Selama menghadapi ancaman penggusuran tersebut, terbukti warga dapat mengorganisasikan diri dengan baik, dengan struktur kepemimpinan formal dan non-formal yang bekerja dengan baik. Kemudian, mengenai stigma negatif perilaku menyimpang yang acapkali dilekatkan pada permukiman informal, data lapangan di Kampung Leuser menunjukkan tidak adanya hal yang demikian. Berdasarkan pengamatan Roberto (2019) dan kesaksian warga, Kampung Leuser adalah kampung yang bebas dari 'penyakit' masyarakat, seperti mabuk-mabukan, penggunaan narkoba, pelacuran, perjudian, dan perbuatan yang mengganggu ketertiban umum lainnya. Kasus pelacuran yang diduga pernah terjadi di rumah kos Tengku, tidak lagi muncul setelah rumah kos tersebut terbakar pada tahun 2001 (Kompas, 30 Agustus 2001). Berdasarkan pengakuan seorang nara sumber, Kampung Leuser bahkan menjadi kampung yang paling aktif dalam kegiatan di Kelurahan maupun Kecamatan.

Masih relatif eratnya ikatan sosial antar-warga dan nilai-nilai yang dianutnya diduga berkaitan dengan riwayat penghunian kampung tersebut. Secara umum, mereka adalah keturunan atau kerabat penghuni awal, yakni beberapa pegawai PAM Jaya. Situasi bermukim yang tidak sepenuhnya aman, 
yakni terancam penggusuran, menimbulkan ikatan yang cukup kuat di antara mereka, dan dorongan untuk terus-menerus membuktikan bahwa permukiman mereka layak secara sosial. Ikatan tersebut tercermin kuat saat warga sama-sama berjuang memenangkan sengketa dengan BPN tersebut.

Kedua hal di atas merefleksikan besarnya investasi sosial dan material yang telah ditanamkan oleh warga Kampung Leuser, secara turun-temurun selama rentang waktu 6 dekade, untuk membangun lingkungan dan kehidupan sosialnya. Di luar argumentasi hukum, investasi sosial dan material inilah yang hendak diketengahkan, untuk mendapatkan haknya bermukim.

\section{Kerangka Metodologis SASF dalam Studi dan Perencanaan Perkotaan}

Penerapan secara luas pendekatan SASF dalam studi dan perencanaan perkotaan memerlukan pendefinisian yang lebih tegas. Ikhtisar berikut merupakan rumusan SASF berdasarkan pembahasan sebelumnya.

Tabel 1. Penerapan Pendekatan SASF dalam Studi dan Perencanaan Kota:

Definisi dan Penjelasannya

\begin{tabular}{|c|c|c|}
\hline No & Konsep & Penjelasannya \\
\hline 1. & SASF & $\begin{array}{l}\text { Lingkungan sosial yang cukup besar, dan/atau telah cukup berkembang, untuk } \\
\text { dapat mengembangkan aturan-pakai (rules-in-use) nya sendiri; namun, juga cukup } \\
\text { kecil, dan/atau cukup submissive, untuk dipengaruhi atau diubah oleh aturan-pakai } \\
\text { dan keputusan yang dipaksakan dari lingkungan yang mengungkungnya. Termasuk } \\
\text { yang disebut terakhir adalah aturan-pakai negara atau kota. }\end{array}$ \\
\hline 2. & $\begin{array}{l}\text { Interaksi- } \\
\text { intensif }\end{array}$ & $\begin{array}{l}\text { Interaksi antara } 2 \text { atau lebih lingkungan sosial tersebut, misalnya SASF dan } \\
\text { lingkungan sosial yang melingkupinya, terjadi pada playing field yang sama, dan } \\
\text { berlangsung intensif, sehingga memungkinkan SASF menyesuaikan diri } \\
\text { sepenuhnya (conformity), melakukan kompromi, atau berbenturan (konflik). }\end{array}$ \\
\hline 3. & $\begin{array}{l}\text { Conformity, } \\
\text { compromize, } \\
\text { conflict }\end{array}$ & $\begin{array}{l}\text { Conformity: terjadi jika SASF submissive sepenuhnya pada aturan-pakai yang } \\
\text { dipaksakan tersebut; } \\
\text { Compromise: terjadi jika SASF dan bidang sosial yang mendominasinya } \\
\text { bernegosiasi dan menemukan kompromi; } \\
\text { Conflict: terjadi jika SASF dan bidang sosial yang melingkupinya memerlukan } \\
\text { waktu yang panjang untuk menemukan titik temu. Sebelum titik temu terjadi, } \\
\text { situasi yang terjadi adalah ketiadaan aturan-pakai yang efektif di lapangan. }\end{array}$ \\
\hline 4. & $\begin{array}{l}\text { Jendela } \\
\text { pengamatan }\end{array}$ & $\begin{array}{l}\text { Adalah pintu masuk atau 'jendela' untuk mengamati, mengenali dan } \\
\text { menginterpretasikan nilai-nilai dan perilaku sosial, juga struktur sosial komunitas } \\
\text { tersebut. 'Jendela' pengamatan ini justru semakin terbuka saat terjadi sengketa } \\
\text { (konflik). }\end{array}$ \\
\hline
\end{tabular}

Pembahasan di atas membuka perspektif baru tentang bagaimana social field tertentu, seperti masyarakat adat, seharusnya diperlakukan. Social field tersebut relatif mapan, unik dan telah exist jauh mendahului keberadaan negara. Karena perjalanan sejarahnya, masyarakat tersebut telah mengembangkan aturan-pakai yang berlaku dan mengikat bagi warganya, termasuk dalam hal tata spasialnya (perletakan bangunan-bangunan, hubungan antara unsur permukiman, mekanisme perubahan dan pergantian, dan seterusnya) dan hal tersebut dapat mengekspresikan tata suku dan tata nilai masyarakat tersebut (Purbadi 2010). Studi Fahmi (2002) menunjukkan bagaimana komunitas mengembangkan dan menjalankan sistem pengaturan dan pengurusan-diri (self governance), mekanisme pengadilan adat (bagi pelanggar) dan sanksinya, dan mekanisme 
pembaruan aturan-pakai. Karena itu, upaya untuk mencari jalan tengah jika terjadi konflik penataan ruang, misalnya dalam penetapan kawasan lindung, yakni skenario win-win solution, yang secara prinsip tidak bertentangan dengan aturan-pakai nasional yang berlaku, jauh lebih bijaksana. Pemahaman ini seyogianya mendorong akademisi, perencana, dan pelaksana rencana tata ruang untuk selalu berusaha memahami sudut pandang pihak lain, dan tidak terjebak secara kaku menjadi corong kebijakan, atau aturan-pakai, tertentu.

Mekanisme rasional dan legal yang tersedia untuk mengakui keberadaan SASF lokal, misalnya (MHA - Masyarakat Hukum Adat), adalah melalui produk hukum yang ada, yakni SK Kepala Daerah. Menurut Sumardjono (2020: 113), hal ini dipandang cukup karena pengukuhan keberadaan MHA bersifat declaratoir (menetapkan suatu keadaan), bukan konstitutif (mengubah, mengganti), sesuai esensi pasal 18 B ayat (2) UUD 1945.

Dengan bahasan di atas, dapat ditafsirkan adanya 2 cara memanfaatkan pendekatan SASF:

Pertama, dengan memahami sejak awal bahwa setiap interaksi-intensif (pertemuan, perbenturan) 2 atau lebih bidang atau lingkungan sosial berpotensi menimbulkan penyesuaian, kompromi, atau konflik. Dengan pemahaman tersebut, maka setiap introduksi kebijakan, termasuk dalam perencanaan perkotaan, dapat menyiapkan langkah untuk mengantisipasinya. Hal ini misalnya relevan pada kasus R/R Aceh: penerapan aturan-pakai nasional pada situasi spesifik Aceh dan pasca-bencana menimbulkan penyesuaian, kompromi dan konflik. Sebagian dari konflik tersebut melahirkan inovasi kelembagaan.

Kedua, situasi konflik dapat dilihat sebagai 'jendela pengamatan' untuk menelaah aturan-pakai dan dinamika suatu bidang sosial tertentu (Lihat Zakaria 2002). Suatu kajian sosial tentang Kampung Leuser, misalnya, dapat menggunakan konflik tersebut sebagai pintu masuk untuk mengamati dan mengenali aturan-pakai, nilai-nilai dan perilaku sosial di dalam komunitas Kampung Leuser tersebut.

\section{KESIMPULAN DAN SARAN}

Pembahasan dan temuan di atas menunjukkan bahwa pendekatan SASF telah dan dapat digunakan secara luas, termasuk dalam studi dan perencanaan perkotaan, untuk memahami fenomena penyesuaian-diri, kompromi, atau konflik yang terjadi ketika suatu aturan-pakai negara/kota diterapkan pada satu SASF tertentu. Khusus berkaitan dengan bidang kajian studi dan perencanaan perkotaan, kesimpulan dan rekomendasi yang dapat ditarik dari pembahasan di atas adalah:

Pertama, suatu panduan tertentu yang berlaku nasional, tidak tepat diterapkan pada situasi khas rekonstruksi pasca-bencana. Salah satu tantangan utama rekonstruksi, yakni segera mengembalikan kehidupan warga ke situasi normal, terancam gagal jika panduan yang ada, yakni UU Penataan Ruang, bersifat terlalu hierarkhis dan prosedural. Begitu juga, penerapan secara kaku kebijakan tentang RTH di Kampung Leuser, dengan mengabaikan fakta bahwa tanah untuk RTH tersebut telah diabaikan selama lebih dari 60 tahun dan tanah tersebut telah dikuasai dan dimanfaatkan dengan baik oleh warga, sungguh berlebihan. Dalam konteks ini, solusi yang memenangkan kedua belah pihak, misalnya menjadikan kampung tersebut sebagai kampung hijau (mendekati tujuan pembuatan RTH), akan jauh lebih realistik. 
Kedua, upaya mengenali, memahami, dan mengakui aturan-pakai lain yang telah berkembang pada berbagai masyarakat lokal (adat) mendorong adanya pluralisme hukum dalam penataan ruang. Daerah, atau lingkungan sosial semi-otonom lainnya, perlu mendapat ruang yang lebih besar dalam penataan ruang, misalnya dengan memperluas pemaknaan (konsep) pola ruang. Inilah yang mungkin dapat disebut paham demokrasi dalam penataan ruang (sebagai kontras terhadap paham efisiensi, sebagaimana model perencanaan hierarkhis yang dianut dalam UU 24/1992 dan UU 26/2007 -keduanya tentang Penataan Ruang). Pertanyaan lebih spesifik, misalnya tentang: apa batas-batas suatu social field? Seberapa jauh kompromi dapat diterima, terutama bagi social system yang melingkupinya, agar tidak menjadi anarkhi? kiranya dapat dikaji secara spesifik pada setiap konteks penerapan pendekatan ini, karena sifatnya yang khas.

Paham pluralisme hukum ini disampaikan dengan menimbang bahwa masyarakat Indonesia terlalu beragam untuk diatur secara tunggal. Kampung atau desa telah hidup jauh sebelum Republik Indonesia terbentuk, atau pengaturan tata ruang tertentu terbentuk. Pengenalan dan pemahaman terhadap aturan-pakai lokal itu di dalam berbagai SASF, khususnya yang berkaitan dengan penataan ruang, perlu terus diupayakan.

\section{REFERENSI}

Davidoff, P. (1965). "Advocacy and Pluralism in Planning". Journal of the American Institute of Planners 31 (4): 331-338.

Fahmi, E. (2019). "Perencanaan Berbasis-Komuntas dalam Rekonstruksi Aceh Pasca-Bencana: Sebuah Refleksi Teoretik”. Jurnal Muara Sains, Teknologi, Kedokteran dan Ilmu Kesehatan Vol 2 No. 2 Oktober 2018, Pp 416-429.

Fahmi, E. and Putra, H.P. (2021). "Community-based Village Planning for the Reconstruction of Post-tsunami and Post-conflict Aceh: Participatory Planning in Practice". In Mickey Lauria and Carissa Schively. Learning from Arnstein' Ladder of Participation. London: Routledge

Fahmi, E. (2002). "Pengaturan dan Pengurusan-sendiri Di Desa Pulau Tengah, Jambi, dan Kontribusinya bagi Administrasi Publik". Disertasi (tidak diterbitkan). Depok: Universitas Indonesia

Friedmann, J. (1987). Planning in the Public Domain: From Knowledge to Action. New Jersey: Princeton University Press

Hudson, B. M, Thomas D. Galloway dan Jerome L. Kaufman. (1979). "Comparison of Current Planning Theories: Counterparts and Contradictions". Journal of American Planning Association 45:4, 387-398

Ihromi, TO. (1993). "Kata Pengantar". Dalam TO Ihromi (eds). Antropologi Hukum: Sebuah Bunga Rampai. Jakarta: Yayasan Obor Indonesia. Pp. ix-xvii

Ihromi, T.O. (1993). "Hukum dan Perubahan Sosial: Bidang Sosial Semi-Otonom Sebagai Suatu Topik Studi yang Tepat”. Dalam TO Ihromi (eds). Antropologi Hukum: Sebuah Bunga Rampai. Jakarta: Yayasan Obor Indonesia. Pp. 148-193.

Moore, S. F. (1973). "Law and Social Change: The Semi-Autonomous Social Field as an Appropriate Field of Study". In Law \& Society Review Vol 7 No. 4 (Summer 1973) Pp. 719746.

Pardede, T.S. dan Tetsuo, K. (2008). “Aceh Reconstruction Planning, Top Down or Bottom-Up Approach? An overview of planning theory and learning from community planning in Aceh 
after tsunami”. Paper presented at the $7^{\text {th }}$ Asian City Planning. Tokyo: City Planning Institute of Japan, 30 November.

Purbadi, Y. (2010). “Tata Suku dan Tata Spasial pada Arsitektur Permukiman Suku Dawan Di Desa Kaenbaun Di Pulau Timor”. Disertasi (tidak dipublikasikan). Yogyakarta: Universitas Gadjah Mada.

Roberto. (2019). "Kampung Leuser: Tantangan dan Prospek Sebuah Permukiman Informal di Kebayoran Baru". Tesis (tidak diterbitkan). Jakarta: Universitas Tarumanagara

Roberto dan Fahmi, E. (2020). "Kampung Leuser: Tantangan dan Prospek Sebuah Permukiman Informal di Kebayoran Baru”. Jurnal Muara (akan terbit). Jakarta: Universitas Tarumanagara

Sumardjono, M. S.W. (2020). Agenda yang Belum Selesai: Refleksi atas Berbagai Kebijakan Pertanahan. Yogyakarta: Fakultas Hukum Universitas Gadjah Mada.

Zakaria, R. Yando. (2002). "Catatan atas Konflik Tanah Di 'Negeri Bersuku-suku'”. Dalam Anu Lounela dan R. Yando Zakaria (eds). Berebut Tanah: Beberapa Kajian Berperspektif Kampus dan Kampung. Yogyakarta: Insist Press 